\title{
Spinal Nerve Root Compositions of Musculocutaneous Nerve: An Anatomical Study
}

\author{
Muskülokutanöz Sinirin Spinal Sinir Kökü Yapısı: \\ Anatomik Bir Çalsşma
}

Emre DEMIRCAY ${ }^{1}$, Ahmet Murat MUSLUMAN $^{2}$, Tufan CANSEVER ${ }^{3}$, Ismail YUCE ${ }^{2}$, Erdinc CIVELEK ${ }^{3}$, Adem YILMAZ2 ${ }^{2}$, Serdar $\mathrm{KABATAS}^{3}$, Taskin $\mathrm{OZDES}^{4}$, Bulent $\mathrm{SAM}^{5}$

${ }^{1}$ Baskent University, School of Medicine, Department of Orthopedic Surgery, Istanbul, Turkey

${ }^{2}$ Sisli Etfal Education and Research Hospital, Clinic of Neurosurgery, Istanbul, Turkey

${ }^{3}$ Baskent University, School of Medicine, Department of Neurosurgery, Istanbul, Turkey

${ }^{4}$ Ministry of Justice, Council of Forensic Medicine, Istanbul, Turkey

${ }_{5}$ National Forensic Institute of Ministry of Justice, Cerrahpasa, Istanbul, Turkey

Corresponding Author: Emre DEMIRCAY / E-mail: emredemircay@hotmail.com

\begin{abstract}
AIM: This study was aimed to investigate the variations in the spinal nerve root compositions of musculocutaneous nerve and to confirm which spinal nerve root is the main ingredient in participating amount.

MATERIAL and METHODS: A total of 20 fresh cadavers were dissected. Brachial plexus and its branches were extracted. Musculocutaneous nerve stump was traced back to the roots to identify its fascicular origin. The number of fascicles originating from a particular nerve root and their axial location with in the nerve were noted.

RESULTS: The most frequent type of spinal nerve compositions of musculocutaneous nerve was $C 5, \mathrm{C} 6$, and $\mathrm{C7}$ with incidence of $60 \%$. Musculocutaneous nerve had bundles from C5 root in all specimens, $90 \%$ of the specimens had contribution from C 6 and only $70 \%$ of them had bundles from C7 root. There were a total of 46 (37.7\%) bundles in C5 fascicles, 48 (39.3\%) bundles in C6 fascicles, and 28 (22.9\%) bundles in C7 fascicles.

CONCLUSIONS: In electrophysiological studies it should be remembered that C7 or C6 lesions may not impair musculocutaneous nerve functions. The success of musculocutaneous nerve neurotization may be improved if care is taken to ensure whether or not C7 root is contributing to the musculocutaneous nerve.
\end{abstract}

KEYWORDS: Musculocutaneous nerve, Cadaver, Spinal nerve roots, Neurotization

öz

AMAÇ: Bu çalışmanın amacı, muskülokutanöz sinirde spinal sinir kökü bileşimi varyasyonlarını araştırmak ve hangi spinal sinir kökünün katılım miktarı olarak ana bileşeni oluşturduğunu doğrulamaktır.

GEREÇ ve YÖNTEM: Toplam 20 taze kadavranın diseksiyonu yapıldı. Brakiyal pleksus ve dallarının ekstraksiyonu gerçekleştirildi. Muskülokutanöz sinir kökü, fasiküler kökenini tanımlamak üzere köklerine kadar geri izlendi. Belirli bir sinir kökünden köken alan fasiküllerin sayısı ve sinir içindeki aksiyal konumları kaydedildi.

BULGULAR: Muskülokutanöz sinirin spinal sinir bileşiminin en sık görülen tipi C5, C6 ve C7'ydi ve insidans \%60'dı. Muskülokutanöz sinirin tüm örneklerinde C5 kökünden demetler varken, örneklerin \%90'ında C6'dan ve sadece \%70'inde C7 kökünden demetler vardı. C5 fasiküllerinde toplam $46(\% 37,7)$, C6 fasiküllerinde $48(\% 39,3)$ ve C7 fasiküllerinde $28(\% 22,9)$ demet vardı.

SONUÇ: Elektrofizyolojik çalışmalarda, C6 veya C7 lezyonlarının muskülokutanöz sinir işlevlerini bozmayabileceğine dikkat edilmelidir. Eğer C7 kökünün muskülokutanöz sinire katkıda bulunup bulunmadığını belirlemeye dikkat edilirse, muskülokutanöz sinir nörotizasyonu başarısı artabilir.

ANAHTAR SÖZCÜKLER: Muskülokutanöz sinir, Kadavra, Spinal sinir kökleri, Nörotizasyon

\section{INTRODUCTION}

The musculocutaneous nerve ( $n$. musculocutaneous) arises from the lateral cord of the brachial plexus, opposite the lower border of the pectoralis minor, its fibers being derived from the fifth, sixth, and seventh cervical nerves (3). In its course through the arm it innervates the coracobrachialis, biceps brachii, and the greater part of the brachialis. It also supplies branches to the skin over the lateral cubital and forearm regions via the lateral antebrachial cutaneous nerve. The biceps provide a significant contribution to overall upper extremity function. Therefore the diagnosis and treatment of musculocutaneous nerve lesions are extremely important. 
Although textbooks describe the origin of the musculocutaneous nerve as the fifth, sixth and seventh cervical nerves, the composition of the nerve itself has not been fully detailed. For example, there are reports on the composition of the branches supplying the coracobrachialis muscle, but we could not find any study in the English literature on the composition of the musculocutaneous nerve itself. This study was aimed at investigating the variations in the spinal nerve compositions of the musculocutaneous nerve and confirmation of which spinal nerve provides the main participating contribution. The Institutional Review Board (IRB) approved all the dissections and procedures.

\section{MATERIAL and METHODS}

A total of 20 fresh cadavers (ten cadavers right side, ten cadavers left side), at 24 hours postmortem, were dissected from neck to axilla with clavicle removed. Scalene muscles were also removed for better exposure (Figure 1A - H). The brachial plexus and its branches were labeled and extracted en bloc after anatomic variations were noted and photographed. The extracted specimens were immersed in $4 \%$ aldehyde sucrose and phosphate buffered saline (PBS) for 6 hours. The musculocutaneous nerve was identified from the branching point from the lateral cord and divided. The musculocutaneous nerve stump on the brachial plexus was dissected under 10x surgical microscope (Carl Zeiss NC4).

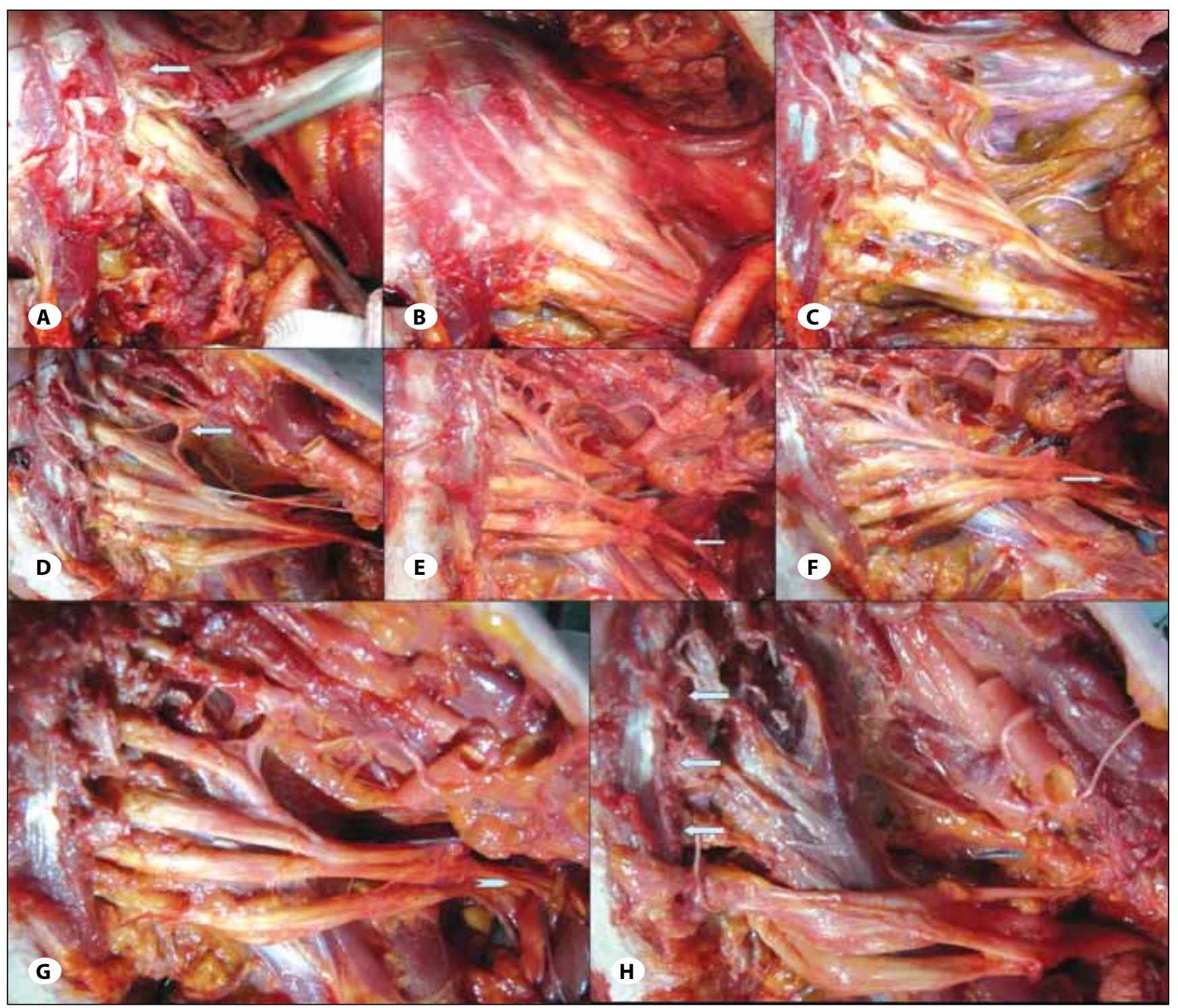

Figure 1: A) Brachial plexus was found posterior to the anterior scalene muscle. Arrow shows anterior scalene muscle. B) Anterior scalene muscle was elevated and spinal roots were exposed (C4, C5, C6, C7, C8, T1). C) Brachial plexus was dissected from the roots to the peripheral nerves in the axilla. D) Prefixed brachial plexus. Arrow shows anastomoses between C4 - C5. E-G) Brachial plexus was demonstrated in different viewing angles. Arrow shows musculocutaneous nerve. H) Roots were divided at a level just distal to the spinal ganglions, anterior to the medial scalene muscle. Arrows are pointing intervertebral foramina. 
The nerve was traced back to the nerve roots to identify its fascicular origin (Figure 2A-D). The number of fascicles originating from a particular nerve root and their axial location within the nerve were noted.

\section{RESULTS}

The most frequent spinal root composition of musculocutaneous nerve was $\mathrm{C} 5, \mathrm{C} 6$, and $\mathrm{C} 7$ ( 12 cases), $\mathrm{C} 5$ and $\mathrm{C} 6$ were seen in 6 cases, and C5 and C7 were seen in two cadavers.
The musculocutaneous nerve had fascicles from $\mathrm{C} 5$ root in all specimens, and $90 \%$ of the specimens had contribution from C6, and only $70 \%$ of them had fascicles from C7 root (Figure 3). In 20 cadavers, the total number of $\mathrm{C} 5$ fascicles contributing to the musculocutaneous nerve was $46(37.7 \%), 48$ (39.3\%) fascicles originated from $\mathrm{C} 6$, and 28 (22.9\%) fascicles originated from $\mathrm{C7}$. C7 fascicles joined to the musculocutaneous nerve distally at the level of divisions in all cases. $C 5$ and C6 fascicles joined proximally at the roots' level in all cases but

Table I: The Axial Distribution of Fascicles in the Musculocutaneous Nerve with Regard to Their Spinal Root Origins. Column Headers are the Axial Location in the Musculocutaneous Nerve Section. The Row Headers are Spinal Root Origins of the Fascicles Forming Musculocutaneous Nerve. The Plain Numbers Indicate the Number of Specimens in Which the Fascicles Originating from Corresponding (Row Header) Spinal Root Occupying A Certain Axial Location (Column Header). The Numbers in the Brackets Indicate Number of Fascicles Originating that Spinal Root Occupying Indicated Location

\begin{tabular}{|c|c|c|c|r|r|}
\hline & Ventral & Dorsal & Cranial & Caudal & Central (ventral - dorsal) \\
\hline C5 & $2(2)$ & & $14(32)$ & $4(12)$ & $2(8)$ \\
\hline C7 & $8(10)$ & $4(8)$ & $2(10)$ & $10(23)$ & $4(14)$ \\
\hline
\end{tabular}

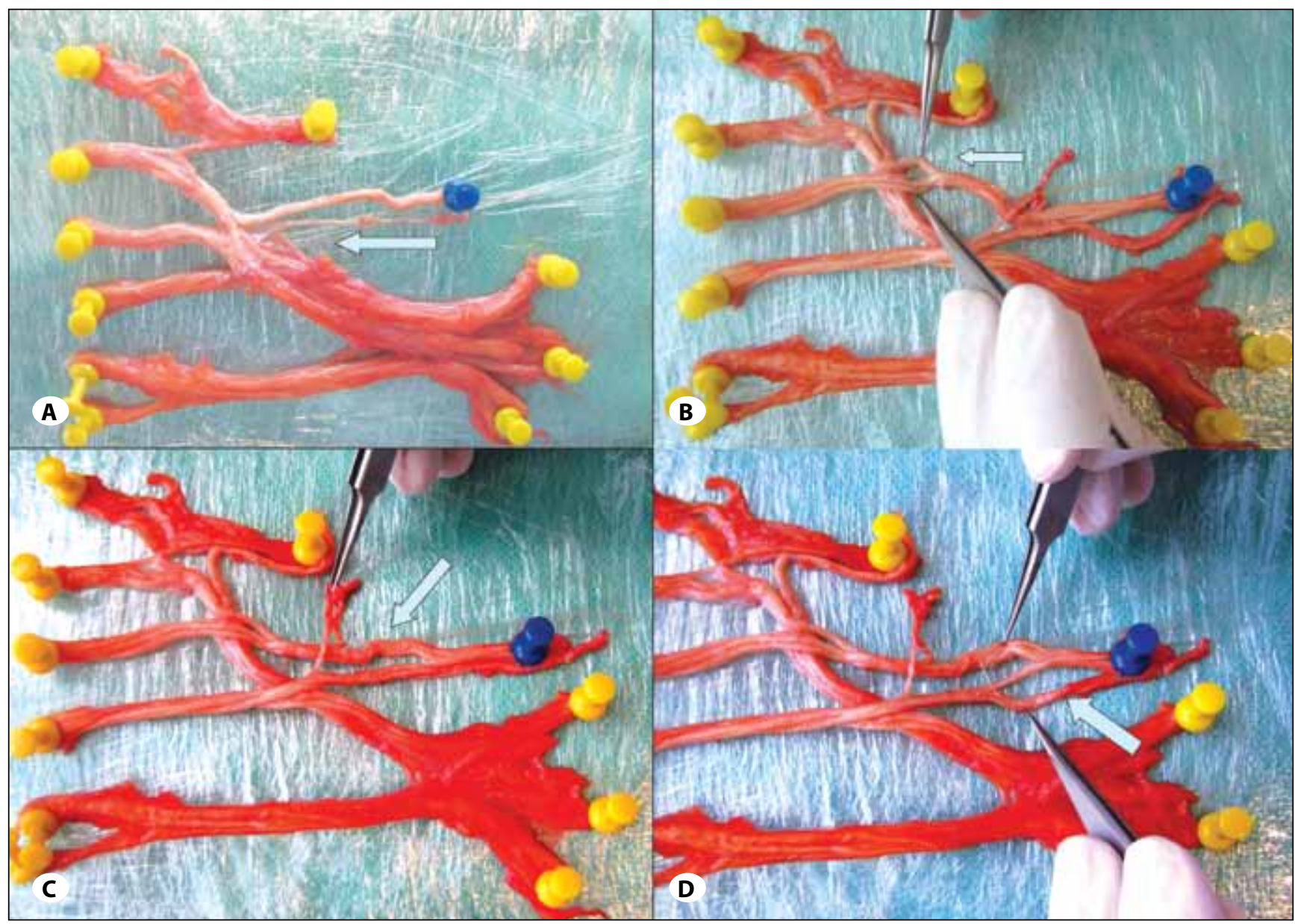

Figure 2: Brachial plexus extracted. A) Arrow shows fascicles from the trunks uniting to form divisions. Blue pin: Suprascapular nerve. B) Arrow shows fascicles being dissected by teasing method. Blue pin: Musculocutaneous nerve. C) Musculocutaneous nerve was dissected into its fascicles and traced back to the nerve roots. Blue pin: Musculocutaneous nerve. D) Fascicles were separated and their spinal root origins were determined. Blue pin: Musculocutaneous nerve. 

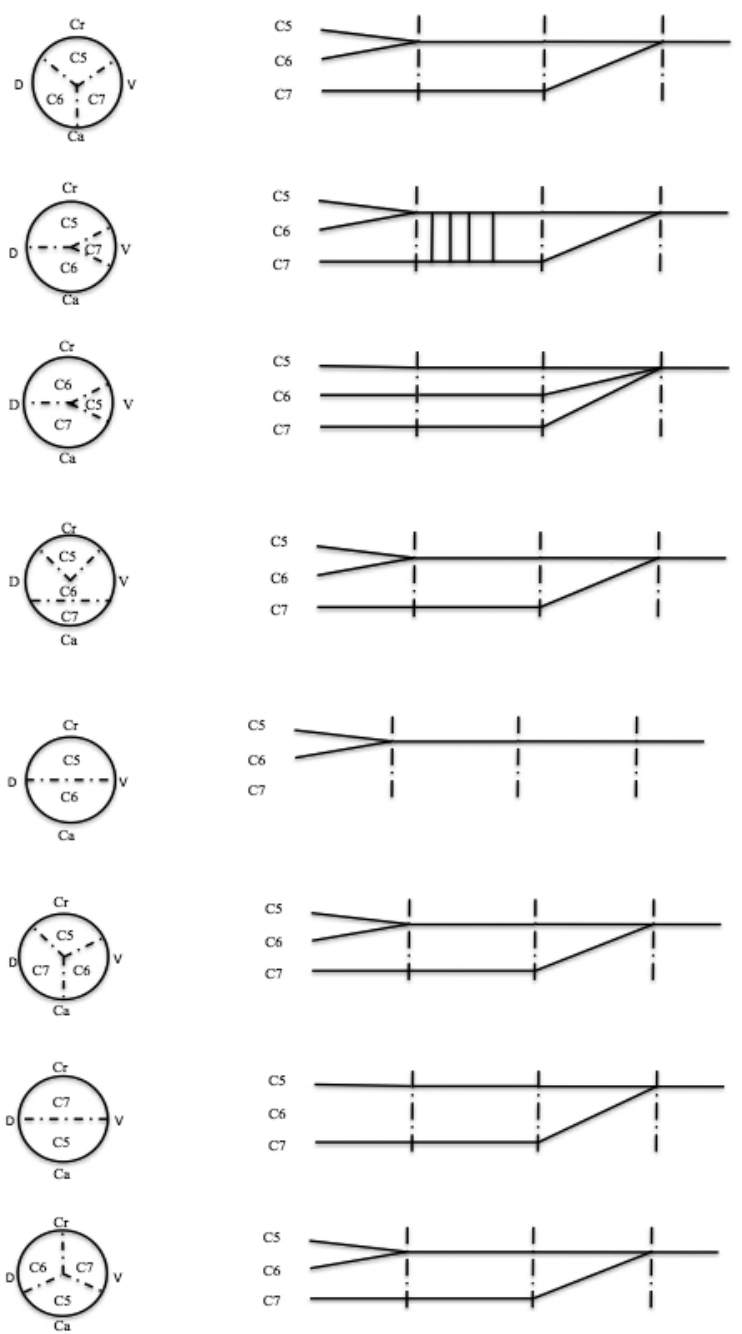

Figure 3: Variations in the axial distribution of spinal root fascicles in musculocutaneous nerve and joining levels of spinal root fascicles to form musculocutaneous nerve. Axial sections represent the proximal musculocutaneous nerve distal to its origin.

Cr: cranial, Ca: caudal, V: ventral, D: dorsal, R: root, T: trunk, D: division.

one; where they joined at the divisions' level with $C 7$ fascicles. The axial distribution of fascicles with regard to their spinal root origins and individual number of fascicles from that spinal root forming the musculocutaneous nerve are given in Table I. C5 fascicles were usually located in the cranial part of the musculocutaneous nerve (70\%), C6 fascicles were usually located caudal (55.5\%), and C7 fascicles were localized to the ventral part of the nerve in $57.1 \%$ of the 14 cases where it was present.

\section{DISCUSSION}

The musculocutaneous nerve is very important in upper extremity function, providing elbow flexion, supination and contributing to shoulder stabilization. Variations of the spinal root compositions of the musculocutaneous nerve and identifying which spinal nerve root provides the main contribution were investigated on fresh cadavers. Lipid parts of the myelin sheath cannot be preserved in embalmed cadavers, but are well preserved in fresh specimens (1). The dissection of spinal roots, brachial plexus, and fascicles are easier in fresh cadavers than embalmed specimens, as there is no need to soften the connective tissue around nerve fascicles $(1,9)$.

We had hoped to identify motor, sensory and autonomous fiber distribution within the musculocutaneous nerve by acetylcholinesterase stain, but were unable to do this due to technical difficulties.

Although there are several reports on variations in the origin and distribution of the nerve the spinal root composition of the nerve itself has not been thoroughly investigated in past literature $(4,5,9)$.

Physical examination of root pathologies requires testing the functions of terminal branches. The functions of a terminal nerve, which is mainly formed by a particular spinal root, reflect integrity of that root. Thus the variations in the spinal root contributions to the terminal nerves are important in diagnosis and decision-making. Impairment of elbow flexion, which usually indicates $C 6$ root pathology, may not be true in $10 \%$ of the cases with respect to this study's results.

Spinal origins of this nerve are important in neurotization procedures in upper brachial plexus injuries, interpretation of electrophysiological studies, and evaluation of cervical radiculopathies.

A number of anatomy textbooks describe the spinal origins of musculocutaneous nerve as $\mathrm{C} 5, \mathrm{C} 6$ and $\mathrm{C} 7$, but there are other authors stating its origins as $C 5, C 6(3,4,6,7)$. The musculocutaneous nerve had fascicles from $\mathrm{C} 5$ in all of the specimens in our study, $90 \%$ of the specimens had C6, and $70 \%$ of the specimens had fascicles from C7. Although C 6 fascicles were not contributing to the musculocutaneous nerve in all of the specimens, the number of fascicles it supplied were (39.3\%) more than both C5 (37.7\%) and C7 (22.9\%).

Several authors indicated partial ipsilateral $C 7$ transfer to the upper trunk for C5 - C6 avulsion of the brachial plexus $(2,8$, $10,11)$. Sectioning of the entire $C 7$ root was not advised due to its potential in increasing the extent of the palsy, and the anterolateral portion of the $\mathrm{C} 7$ root was proposed as a donor. Musculocutaneous nerve contribution of the anterolateral portion of $\mathrm{C} 7$ root has not been detailed in the literature. In $70 \%$ of our specimens there was a C7 contribution to the musculocutaneous nerve. Therefore, before considering partial ipsilateral C7 transfer, it may be beneficial to investigate its contribution to musculocutaneous nerve.

In electrophysiological studies it should be remembered that C7 or C6 lesions may not impair musculocutaneous nerve functions, and in $10 \%$ of our specimens the musculocutaneous 
nerve did not have any contribution from a C 6 root and there was no contribution from C7 in $30 \%$ of the specimens.

Neurotization of the musculocutaneous nerve with an ipsilateral C7 root is suggested by many authors in upper brachial plexus injuries. The success of this technique may be improved if care is taken to ensure whether or not the C7 root is contributing to the musculocutaneous nerve. In $30 \%$ of cases, C7 is not contributing to the musculocutaneous nerve, and in these patients neurotization of musculocutaneous nerve with a $\mathrm{C} 7$ root may yield better results.

\section{ACKNOWLEDGMENTS}

This study was performed at Baskent University School of Medicine, Istanbul, Turkey and National Forensic Institute of Ministry of Justice, Cerrahpasa, Istanbul, Turkey.

\section{REFERENCES}

1. Chatyingmongkol K, Roongruangchai J, Sripaoraya K: Histological and ultrastructure of the peripheral nerve in cadaveric embalmed specimens and in fresh cadavers: The efficacy of several fixatives. Siriraj Med J 61:16-19, 2009

2. Gu YD, Cai PQ, Xu F, Peng F, Chen L: Clinical application of ipsilateral C7 nerve root transfer for treatment of C5 and C6 avulsion of brachial plexus. Microsurgery 23:105-108, 2003

3. Johnson D: Pectoral girdle, shoulder region and axilla. In: Standring S (ed), Gray's Anatomy: The Anatomical Basis of Clinical Practice. $40^{\text {th }}$ ed. Spain: Churchill Livingstone Elsevier, 2008:791-823
4. Osborne AW, Birch RM, Munshi P, Bonney G: The musculocutaneous nerve. J Bone Joint Surg Br 82:1140-1142, 2000

5. Ozturk A, Bayraktar B, Taskara N, Kale AC, Kutlu C, Cecen $A$ : Morphometric study of the nerves entering into the coracobrachialis muscle. Surg Radiol Anat 27:308-311, 2005

6. Robinson A: Cunningham's Text Book of Anatomy. $5^{\text {th }}$ ed. New York, NY: William Wood and Co 1918

7. Snell SR: Clinical Anatomy by Regions. $9^{\text {th }}$ ed. Baltimore, MD: Lippincott Williams \& Wilkins, 2012

8. Song J, Chen L, Gu YD: Functional compensative mechanism of upper limb with root avulsion of $C(5)-C(6)$ of brachial plexus after ipsilateral $C(7)$ transfer. Chin J Traumatol 11: 232-238, 2008

9. Woo JS, Shin C, Hur MS, Kang BS, Park SY, Lee KS: Spinal origins of the nerve branches innervating the coracobrachialis muscle: Clinical implications. Surg Radiol Anat 32:659-662, 2010

10. Xu JG, Gu YD, Wang H, Hu SN, Yong Chen Z: Comparative experimental study on treatment outcome of nerve transfer, using selective $\mathrm{C7}$ nerve root vs. phrenic nerve. Microsurgery 24:143-146, 2004

11. Yin HW, Jiang $S, X u$ WD, Xu L, Xu JG, Gu YD: Partial ipsilateral C7 transfer to the upper trunk for C5-C6 avulsion of the brachial plexus. Neurosurgery 70:1176-1181, 2012 